\title{
Cyclone Incinerator
}

\section{Development Program}

\section{for July 1976}

\section{DISCLAIMER}

This report was prepared as an account of work sponsored by an agency of the United States Government. Neither the United States Government nor any agency thereof, nor any of their employees, makes any warranty, express or implied, or assumes any legal liability or responsibility for the accuracy, completeness, or usefulness of any information, apparatus, product, or process disclosed, or represents that its use would not infringe privately owned rights. Reference herein to any specific commercial product, process, or service by trade name, trademark, manufacturer, or otherwise does not necessarily constitute or imply its endorsement, recommendation, or favoring by the United States Government or any agency thereof. The views and opinions of authors expressed herein do not necessarily state or reflect those of the United States Government or any agency thereof.
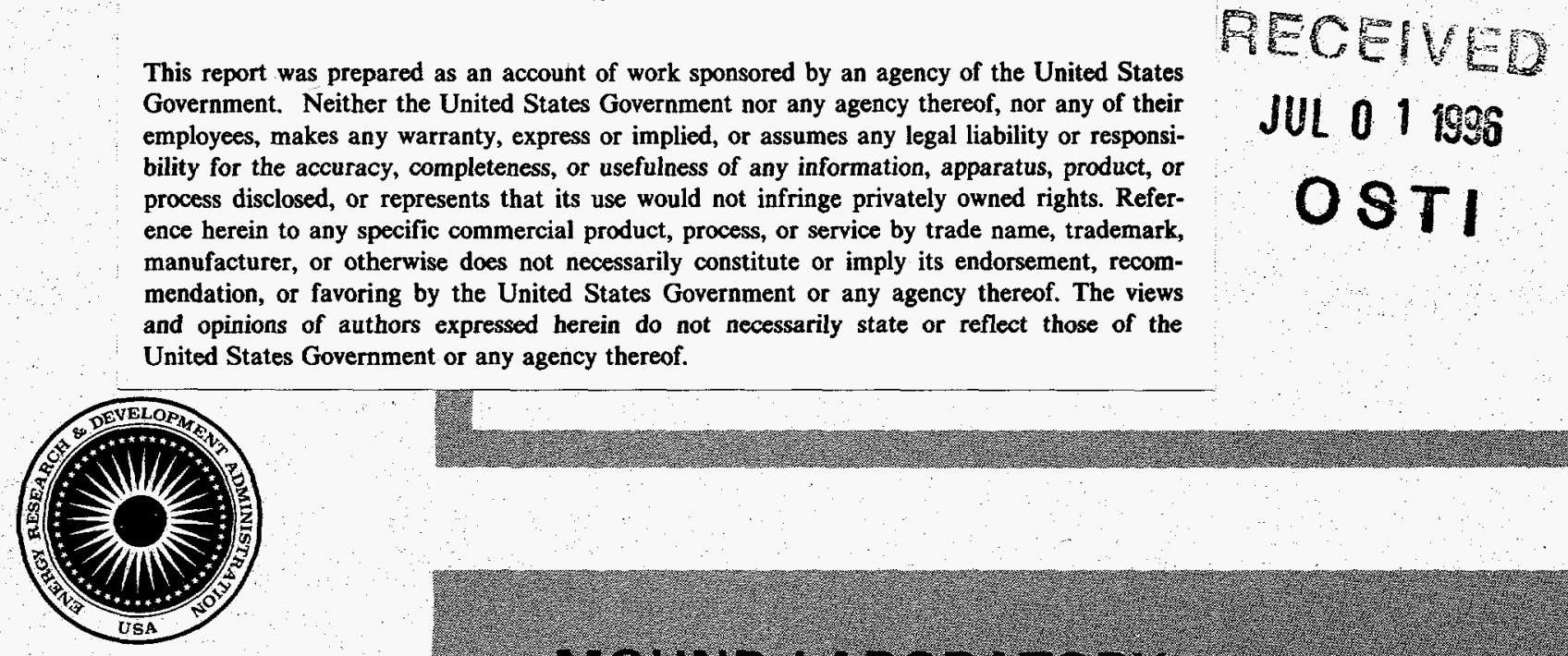

\section{MOUND LABORATORY}

Miamisburg. Ohio

operated by

MONSANTO RESEARGH CORPORATION

a subsidiary of Monsanto Company

for the

UNITED STATES ENERGY RESEARCH

AND DEVELOPMENT ADMINISTRATION

U. S. Government Contract No E-33-1-GEN-53

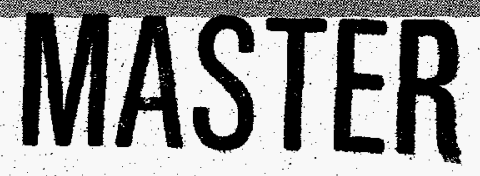


MLM-MU-76-67-0003

\section{Cyclone Incinerator Development Program for July 1976}

Issued: September 23, 1976

MONSANTO RESEARCH CORPORATION

A Subsidiary of Monsanto Company

\section{MOUND IABORATORY}

Miamisburg, Ohio

45342

operated for

\section{UNITED STATES ENERGY RESEARCH AND DEVELOPMENT ADMINISTRATION}

U.S. Government Contract No. E-33-1-GEN-53 


\section{DISCLAIMER}

Portions of this document may be illegible in electronic image products. Images are produced from the best available original document. 
DISTRIBUTION

\section{External}

J. A. Chacon, ERDA/DAO

D. Davis, ERDA/ALO (2)

R. A. Wolfe, ERDA/DNFCP

\section{Internal}

A. G. Barnett

R. K. Blauvelt

J. D. Braun

W. T. Cave

B. D. Craft

D. A. Edling

R. K. Flitcraft

S. S. Freeman

K. V. Gilbert

E. W. Johnson

L. V. Jones

D. P. Kelly

B. R. Kokenge

D. F. Luthy

J. R. McClain

D. L. Prosser

J. E. Todd

R. E. Vallée

H. L. Williams

Library (15)

Technical Publications

(3) 
MONTHLY PROGRESS REPORT

July 1 through July 30,1976

\section{INTRODUCTION}

Effort continues to determine the parameters for maximizing the operating efficiency of the off-gas system and the venturi scrubber. Results for the month show a decrease in particulate emissions from the system.

Engineering designs are being finalized for enclosures to permit the introduction of radioactive waste into the incinerator and the handling of the resultant ash. Concurrent with these improvements, the cooling system capacity will be increased to handle more heat in the off-gas as a result of continuous operation. Additional cooling capacity will also be required to protect the burning chamber enclosure.

In July, a HEPA filter was installed on the final exhaust to demonstrate that premature loading of the filter would not be a problem when incinerating radioactive waste.

\section{PARTICULATE EMISSIONS BELOW EPA STANDARD}

During the month, particulate data were collected for twentynine runs. The data obtained are summarized in Table I.

Flue-gases were sampled to determine particle size and concentration at the incinerator chamber outlet, deluge tank outlet and the venturi scrubber outlet. Particulate loading in the off-gas stream averaged $15.4 \mathrm{mg} / \mathrm{cf}$ at the incinerator outlet, $8.4 \mathrm{mg} / \mathrm{cf}$ at the deluge tank outlet and $1.0 \mathrm{mg} / \mathrm{cf}$ at the venturi scrubber outlet. The efficiency of the spray tank and venturi scrubber in removing particles generated by the three types of waste being burned are summarized in Table II and III respectively. The compositions of the three types are shown in Table IV.

The Environmental Protection Agency standard for stack emission of particulates for industrial incinerators of up to 100 pounds per hour capacity, is 0.2 pound per 100 pounds feed $(2 \mathrm{~g} / \mathrm{Kg}$ feed). The addition of the venturi scrubber has reduced the total particulate emissions to 0.88 grams particulate per kilogram of feed at the venturi scrubber outlet. 
TABLE I

SUMMARY OF RESULTS FROM INCINERATOR RUNS

FOR JULY 1976

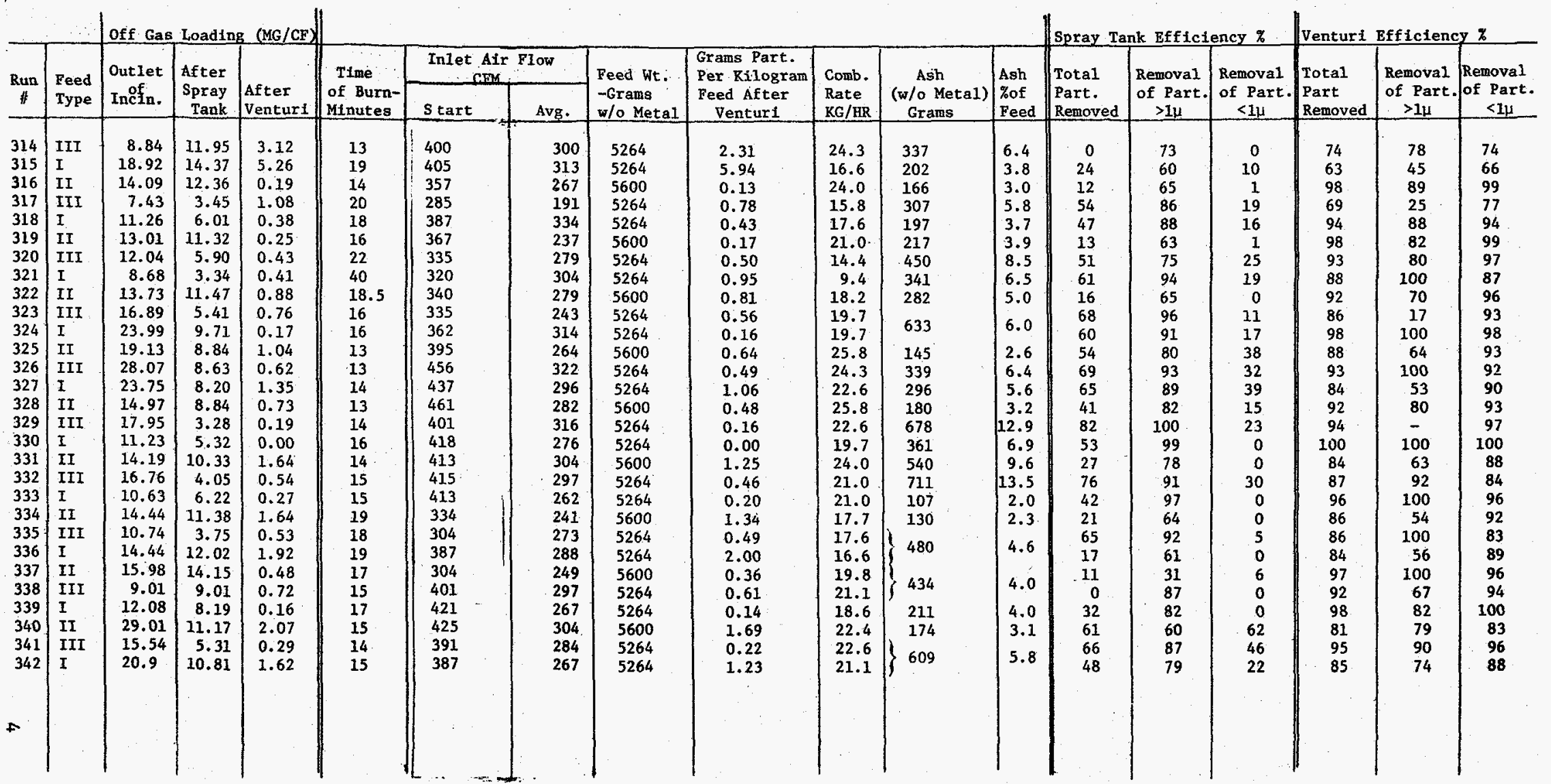




\section{TABLE II \\ EFFICIENCY OF SPRAY TANK \\ IN REMOVING PARTICULATES}

Type I Feed

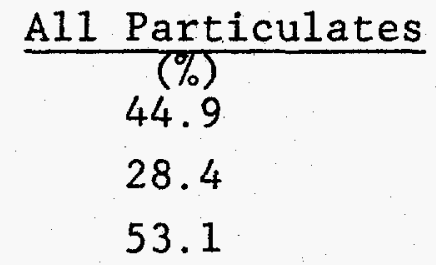

$\frac{>1 \text { Micron }}{(\%)}$

84.0

$\leq 1$ Micron

(\%)

12.3

Type II Feed

Type III Feed

53.1

65.3

13.7

88.0

19.1

TABLE III

EFFICIENCY OF VENTURI SCRUBBER

IN REMOVING PARTICULATES

$\begin{array}{ccc}\text { Al1 Particulates } & \frac{>1 \text { Micron }}{(\%)} & \frac{\leq 1 \text { Micron }}{(\%)} \\ 89.0 & 79.8 & 90.8 \\ 90.7 & 75.7 & 93.2 \\ 86.9 & 72.1 & 88.7\end{array}$




\section{TABLE IV}

\section{COMPOSITION OF INCINERATOR FEEDS}

Type I $^{(1)}$

Paper

Plastics

PVC

Polyethylene

Polypropylene

Rubber

Cloth

Leather

Wood

Meta1
32

Type II ${ }^{(1)}$

9

29

8

13

3

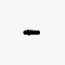

$-$

6
2

48

Type III ${ }^{(1)}$

23

9

2

3

61

26

6

7

6

(1) Weight \% 


\section{USE OF A HEPA FILTER TO DETERMINE PARTICULATE LOADING}

A HEPA filter was installed in the discharge line beyond the venturi scrubber to ascertain the effectiveness of the scrubber in protecting the filter bank from excessive particulates. Twenty-one runs were made with the filter in the system during July. The measured pressure drop increase was 1.38 inches water gauge at $300 \mathrm{cfm}$, over this period. Extrapolation of these data indicated that approximately 146 kilograms of feed could be incinerated before a pressure drop of 2 inches water gauge is incurred or 640 kilograms before a pressure drop of 8 inches is incurred.

These figures are pessimistic because use of the filter was initiated at the same time that the venturi scrubber was installed. After the installation was completed, some time was needed to establish parameters to minimize the quantity of particulates leaving the scrubber. Continued use of the filter would not reflect the improvement incorporated into the operation of the scrubber. Therefore, the filter was replaced with a new one to obtain more realistic data. It is anticipated that the new filter will have a much longer life than that which had been projected for the original one. Data obtained to date with the new filter indicate that the particulate loading has decreased compared to that obtained with the original one.

\section{MODIFICATIONS OF INCINERATOR SYSTEM IN SUPPORT OF FUTURE} OPERATION

Design work was started this month to improve the following aspects of the incinerator system:

1. Radioactive feed handling.

2. Heat dissipation from the burning chamber enclosure.

3. Increased capacity for off-gas cooling.

These changes will permit the handling of $<100 \mathrm{nCi} / \mathrm{g}$ combustible waste and the resultant ash. They include an enclosure for the burning chamber, control of contamination during the loading of the burning chamber and a contained ash handling facility. The burning chamber enclosure will require cooling due to its proximity to the burning chamber. Liquid cooling furnished by the incinerator cooling system was chosen as the most effective method because additional liquid cooling capacity will be necessary to maintain the off-gas temperature at current levels during planned continuous feed operations. Therefore, the two changes can be made as one modification of the present cooling system. 
PLANNED MILESTONES FOR FY-1976A

Efforts in FY-1976A will primarily consist of preparations for incinerating contaminated waste. (See Milestone Chart attached.)

Milestone A will provide information and, possibly, modifications to the existing incinerator required to enable burning in 30 , 55 or 83-gallon drums. Presently, combustibles are stored in all three sizes of drums at various ERDA sites; therefore, it would be advantageous to burn in-situ from any of these drums.

Milestone $B$ will result in written procedures for safely handling drums of contaminated trash before and during incineration and for handling the ash following incineration.

Milestone $C$ will result in enclosures around the burning and ash handling areas to contain radioactive particulates. 


\section{CYCLONE INCINERATOR PROJECT \\ MILESTONE CHART \\ $F Y-1976 A$}

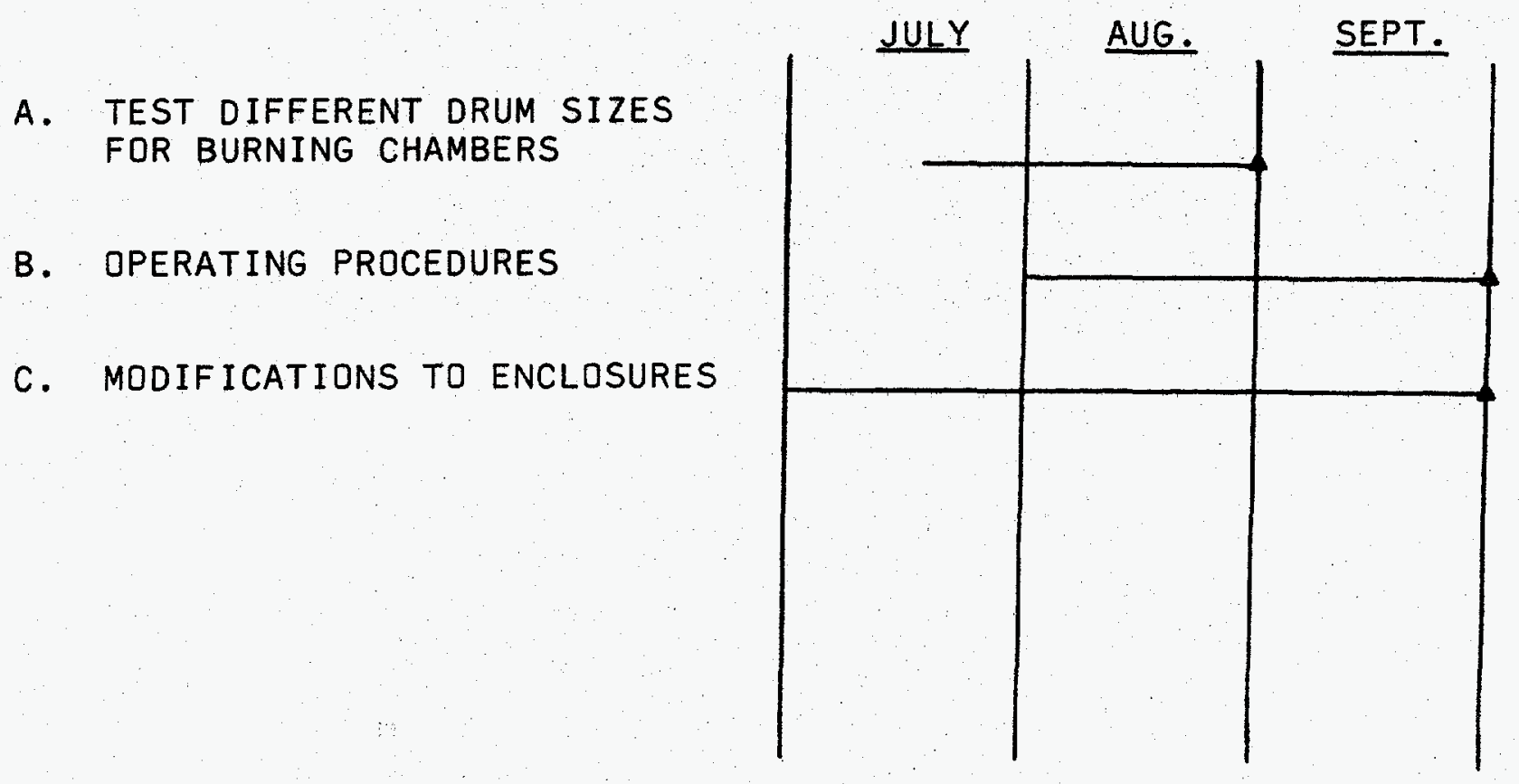

